\title{
今次戦争が老年期養老院收容者の血圧に 及ばした影響について
}

日本医科大学解剖学教空（指学金子北之助数授）

传久間達夫

Tatsuo Sakuma

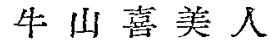

Kimito Ushiyama
緒言

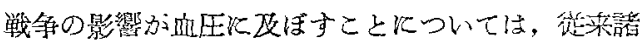

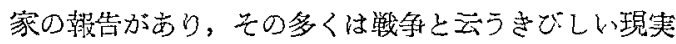
が人閥の食生活记著しい耐泛生活を強いる結照，必然

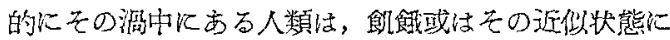

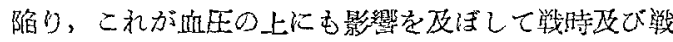
後仙的压が低くなると考光られている。また戦争占

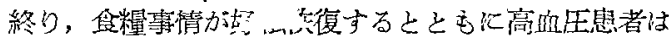
增加すると考克られている。

このことは，人間の食生漂がいか炕血压の上飞大き な影留をむつかを知ることの证来る好適な証左である と思かれる。しかしながら血代を高くする因子性食生 活のよし曾しのみではない。中沢教授は高血圧症は遗 伝と環境とがす因をなす作暂性疾患であると主張して

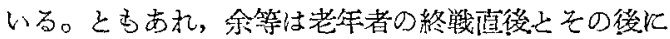
於ける抯圧を測定して，この両者を比較検討する機会 を得たので茲行報告する。

\section{被湌者及び測定方法}

被検渚は東京都，神奈川県の養老院に收宾されてい る 61 瓷以上の老年期健常诸で昭和 21 24 年の者 398 各( 今 111 名 9287 名) 及び昭和 25 27年の者 447 各(る111名早336名)である。

血王湘定には、ルス水銀血压計を男い，疆診法に上

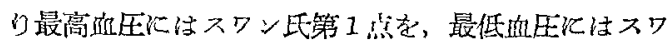
ン氏第4点を抧び，原則として右上坨勳脤を，卧位際 㑕の体位で测定した。

\section{挨 查 成 績}

a) 終戦淔後上その後化於的る最高血在及び最低船 圧の平均值の比較。

袁】飞見られる如く第1老年期《於いても，第 2 老

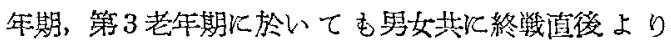
（昭和 24 年度まで）もとの後炕於けるもの（昭和 25 年以降) の方が最高䍀压，最低助压とも火高くなって いる。

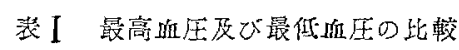

\begin{tabular}{|c|c|c|c|c|c|c|c|}
\hline & \multicolumn{3}{|c|}{ 昭和 24 年以前 } & \multicolumn{3}{|c|}{ 照和 25 年以後 } \\
\hline & & 例数 & 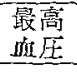 & 賈促 & 例数 & $\begin{array}{l}\text { 最高 } \\
\text { 监压 }\end{array}$ & $\begin{array}{l}\text { 最呧 } \\
\text { 血压 }\end{array}$ \\
\hline \multirow{2}{*}{$61 \sim 70$} & $\hat{o}$ & 48 & 144.9 & 84.2 & 60 & 152.5 & 87.4 \\
\hline & q & 117 & 154.5 & 84.3 & 128 & 170.1 & 95.0 \\
\hline \multirow{2}{*}{$71 \sim 80$} & $\hat{o}$ & 52 & 144.8 & 87.2 & 46 & 175.9 & 95.0 \\
\hline & 우 & 144 & 153.4 & 84.2 & 176 & 165.0 & 91.7 \\
\hline \multirow{2}{*}{$31 \sim$ 以 } & $\delta$ & 11 & 143.0 & 84.1 & 5 & 154.4 & 90.8 \\
\hline & q & 26 & 161.4 & 80.8 & 32 & 174.2 & 99.6 \\
\hline
\end{tabular}

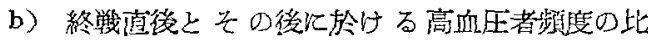
較。

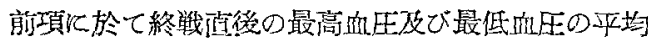
値はそれ以啳のもの此して，いずれる低いという事

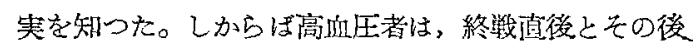
飞於いて，その出現頻度はどうであらうか。表【にみ る如く，昭和 25 年上降のものは昭和 24 年以前のもの 上りも藷しくその頻度を增している。

\section{表 II 高的王者の頻度の比較}

\begin{tabular}{|c|c|c|c|}
\hline 年合 & & 昭和 24 年以前 & 昭和 25 年以降 \\
\hline \multirow{2}{*}{$61 \sim 70$} & $\delta$ & $43.8 \%$ & $51.7 \%$ \\
\hline & 우 & $.41 .0 \%$ & $76.6 \%$ \\
\hline \multirow{2}{*}{$71 \sim 80$} & $\hat{8}$ & $55.8 \%$ & $78.3 \%$ \\
\hline & 우 & $51.4 \%$ & $73.3 \%$ \\
\hline \multirow{2}{*}{$81 \sim$ 以 } & $\delta$ & $36.4 \%$ & $60.0 \%$ \\
\hline & 우 & $61.5 \%$ & $78.1 \%$ \\
\hline
\end{tabular}

c）最低血姫が $90 \mathrm{~mm}$ 以上の高血圧者の此較。

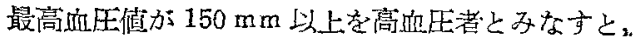


$-50-(400)$

老年期になると念激に鬲血氐者が增加することは，既 凤 Wetherby, Master, 讲山等の赫告する所である。

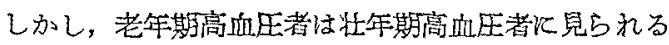

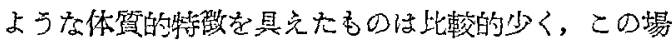

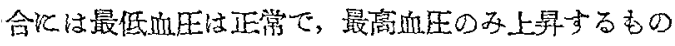
が多いと考古りれ，またこ礼が老年期高血圧者の特致 であるとされている。

Russek 等は老年期の血压を謂套し，最高船压は年

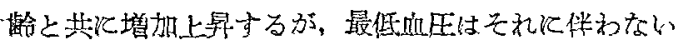
ことを指摘し，本態性高血在症との鑑别の指針として いる。住々康平は最高のみ高く，最低が正常かまたは

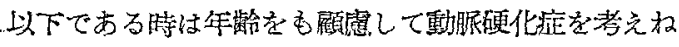

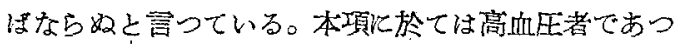
て最低血压が $90 \mathrm{~mm}$ 以上のものについて検討してみ ることにする。

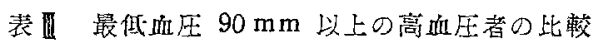

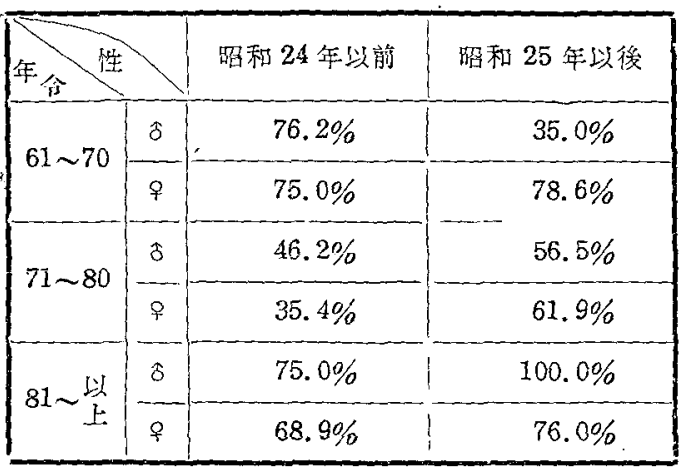

袁近火よつてみると，第一老年期の男子の場会のみ

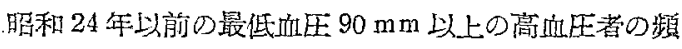
度が炤和 25年以降のものよりも多くなつている。他

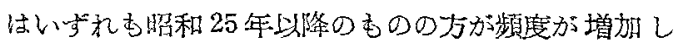
ている。すな放以上の結罚から，栄盖状態がよくな

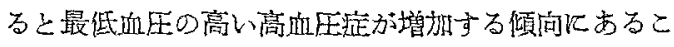
とを推测させる。

\section{考按}

栄徒が血压に变化を与克るであるうことについては 既に多くの記載がある。ことに藏血王者の治源に间つ て栄蒦の問題が重要視さ机なければならないという点

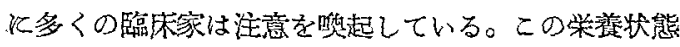
と直接の関俰をるつものが践争である。戦争が今次大

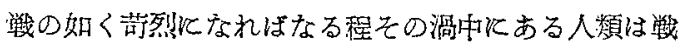
時中戦後ともに飭餓状態焰る。浅野はかかるが故に 昭和 19,20,21,22 年飞海血代者心著しく減少したと 赧告している。余の例に於いても，昭和 24 年以前上 昭和 25 年以降とを比較してみると，昭和 25 年以降の
カが最商血压，最低血压いずれむ高くなつている。

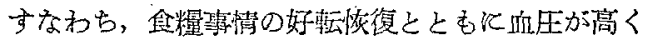
なつたものと考えられる以上の結些炕っつて栄盖状熊

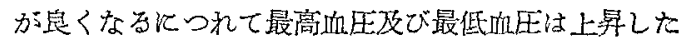
ことが判明した。

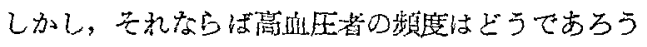

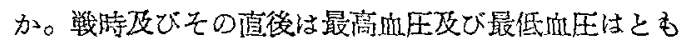
低いが，商血压者の频度むや经り低いであるうか，

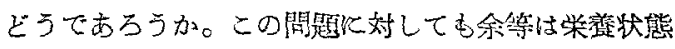
が好軾恢復するとともに高血压者の頻度は堌加するこ

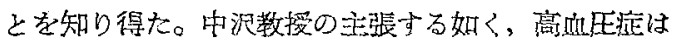

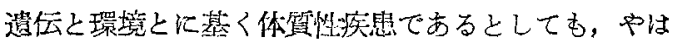
り栄養と云う問題は整視山来ない。

一方老年期には，高血压者が急增するこ上る諸生輩 は教觉ている。そしてその原因の多くを動服硬化に基

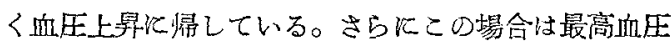

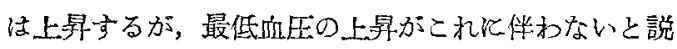
明している。獣争化よつて低下した栄善状態が恢復す

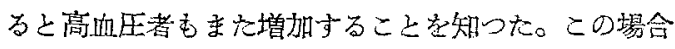

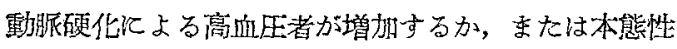

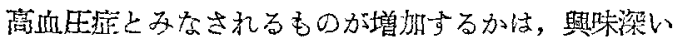
問題でむる。余等の調查結果心，最低血压 $90 \mathrm{~mm}$ 以 上のものも增加していることを示している。すなわち， 籍堆状態加よくなると，高血压者は增加する。即与本

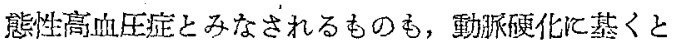

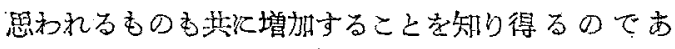
る。以上の事奏加ら栄蕉状態のよ乙雭しは血化を左右

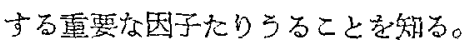

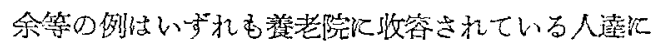
ついての謂查であつて，失々独立生活を㗬九でいる人

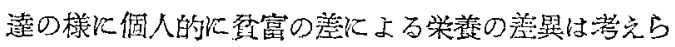
れない。その時々の唒給量たけで生活している集団で

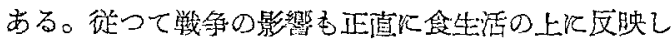
ていると考えて善しいかえない上思方れる。

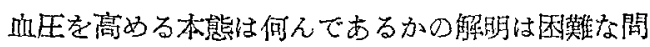
題であり，その解明飞向つて絶えぎる研究娢力が繶け られているのが現状であるが，栄荃の問題も看過でき

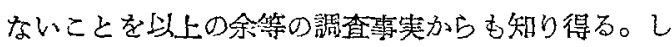

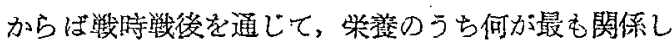

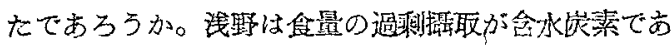

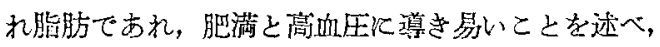

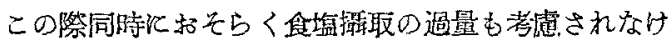
ればならないと説いている。多くの学者の䂥究業績を

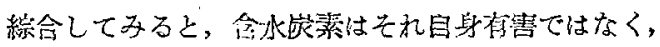


その過剩搨取か肥满を来たすととに意義があると云つ ている。乙かもこの場合肥満そのものが悪いのでなく 高血圧性体質の上肥满と云う条件が加わることが恶 いと説く者むある。

脂肪は Cholesterol が重要な意義を持つと説く者 むあるが，一うこのものは動眽硬化を起すのK役立つ と説く者もあり，結局高血圧と脂肪との関係とついて 恃今後さらに研究を要する段階にあるようである。

蛋白質はそれ自身で高血圧症の原因とはならず，む 乙ろ蛋白質の重要性の最も強調されている現代の栄盖 学の結論加らすれば治療的炕も著しい简障碍がない限 り蛋白制限の必要はないという。また一力良貿の蛋白 は肝機能を却つてよくするから有益であるとさえ説く 者がある現状である。食垍はその作用機序はともかく 高血压に対して㰁めて大なる意義を有していることは すで多くの学者によりて説かれている。それ故にこ 乞高血压症の治療淌つて低食瑥療法が推奖されてい

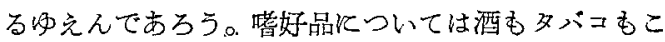
れが原因で高血压を薏起するとは考党られない上らで ある。しかしすで高血圧の起つているすのが酒，タ バコを濫用することはいい影留を与克ないようであ る。

さて，終戦後の主食配給状態讨どうであつたである うか，主食としての米の配給は殆えどなくその代替品 として小麦枌，トウモロコシ粉，砂糖，蠸詰類，グリ

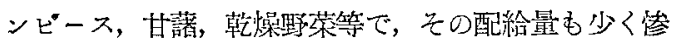
㗹たる状態であつたことは今佮吾人の記憶新たな所

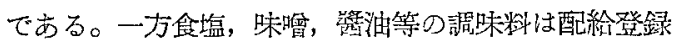
業者の言によると，昭和 21 年は縤争中の苧蔵品で窆 うごて配紷は嚄保できたが，昭和 22 年にはこれ等の 貯蔵品もなくなり，配給化も事欠く状態ですつともみ じめな年であつたという。その後昭和 23 年火はやや 恢復し，昭和 24 年にはさらによくなり，この年の 10 月汇配給制度はなくなり自由眨壳制になるをで至つ たという。かくみてくるとき主食の配給のすくないて
と及びその代替品でみじめであつたことは当然紷戦後 の日本人の栄養状態を極端恶くしたであろうと考克 られる。一方血生と深い関係汇おる食㙁についてみる と如上の状態であつた。ことに養老院の如き收容機関 にいる人達は配給量のみで満足しなければならない状 態であつたのは当然であうう。従つて血闰も終戦直後 より昭和 24 年頃までは下り，それ以挠は上杽したと 苃えていいと思われる。

\section{総括及び結論}

戦争がその瀜中にある人類の食生活に影瑯を灭ぼし その結果人類の栄盖状態飞変化を与え，この事が閒接

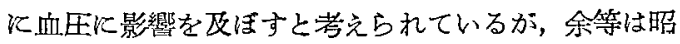
和24年以前の老年期健常者 398 名之昭和 25 年以降の 老年期健常者 447 名について血圧を測定して，次のこ とを結論的吙り得た。

1）最高血圧及び最低血压はともに終戦直後は低い が，食糧事情が好転し栄䖭状態がよくなるとそのいず れも高くなつている。

2）高血王症はやはり栄荃恢復ととむに增加してい る。

3）高血圧者であつてしかお最低血圧が $90 \mathrm{~mm}$ 以 上あるものもまた栄荃恢復とともに増加の傾向を示し ているる。

4）食塩及び味噌，慜油等の配給状態と血生との間 には深い関係があつたように思われる。

稿を終るに隐み御指等いた心゙いた金子教授，御柲閭 を賜つた本学内科赤朴教授江染游するとともに，種尔 御協力下さつた諸団体汇厚く御礼申上げる。

$$
\text { 交献 }
$$

1）牛山喜美人：日医大誌，20,635（1953）

2) 浅野詪一：診燃, 6, 829 (1953)

3）佳々硛平：日本医事新報，No. 1515，68 (1953)

4) 中沢房吉：䛦療, 6, 845 (1953)

5）美亓義夫外：日本医事新報，No. 1551，3 (1954)

6) 村上元孝：診断と治㙩，41，(5)，8 (1953) 